\title{
DENGAN MENGGUNAKAN METODE AHP (ANALYTICAL HIREARCHY PROCESS) MENENTUKAN OBAT SARIAWAN YANG PALING BANYAK DIMINATI MASYARAKAT
}

\author{
Leon Deon', Poningsih², Jalaluddin ${ }^{3}$ \\ ${ }^{1}$ Mahasiswa Program Studi Sistem Informasi STIKOM Tunas Bangsa Pematang Siantar \\ ${ }^{2,3}$ AMIK Tunas Bangsa Pematangsiantar, Indonesia \\ Email: ${ }^{1}$ leondeon99@gmail.com, ${ }^{2}$ poningsih@amiktunasbangsa.ac.id, ${ }^{3}$ jalaluddin@amiktunasbangsa.ac.id
}

\begin{abstract}
Abstrak
Banyak produk obat sariawan yang dipasarkan ke masyarakat. Karena banyak produk yang dipasarkan, membuat masyarakat bingung dalam memilih obat panas dalam yang paling terbaik. Obat sariawan yang paling banyak diminati masyarakat mengartikan bahwa obat tersebut merupakan obat yang terbaik bagi masyarakat. Dalam penelitian ini terdapat dua masalah utama dalam penelitian yang dapat dirumuskan yaitu apakah penggunaan metode $A H P$ ini dapat mengambil keputusan menentukan obat sariawan yang paling banyak diminati masyarakat dan bagaimana mencari keputusan obat sariawan paling banyak diminati masyarakat. Metode Analytic Hierarchy Process (AHP) digunakan untuk menemukan skala rasio, baik dari perbandingan berpasangan yang diskrit maupun kontinyu. AHP menguraikan masalah multi faktor atau multi kriteria yang kompleks menjadi suatu hirarki. Hirarki didefenisikan sebagai suatu representasi dari sebuah permasalahan yang komplek dalam suatu struktur multi level dimana level pertama adalah tujuan,yang diikuti level faktor, kriteria, sub kriteria, dan seterusnya ke bawah hingga level terakhir dari alternatif.
\end{abstract}

Kata kunci: Sistem Pendukung Keputusan, Metode Analytic Hierarchy Process, Obat Panas Dalam

\begin{abstract}
Many hot medicine products are marketed to the public. Because many products are marketed, making people confused in choosing the best hot medicine in the best. Hot medicine in the most popular community means that the drug is the best medicine for the community. In this research, there are two main problems in the research that can be formulated, namely whether the use of the AHP method can make the decision to determine the heat medication in the most popular community and how to look for a hot medicine decision in the most popular community. Analytic Hierarchy Process (AHP) method is used to find the ratio scale, both from discrete and continuous pair comparisons. AHP decomposes complex multi-factor or multi-criteria problems into a hierarchy. Hierarchy is defined as a representation of a complex problem in a multi-level structure where the first level is the goal, followed by the level of factors, criteria, sub-criteria, and so on down to the last level of alternatives.
\end{abstract}

Keywords: Decision Support System, Analytic Hierarchy Process Method, Internal Medicine

\section{PENDAHULUAN}

Perkembangan teknologi informasi seiring berkaitan dengan pengambilan keputusan. Keputusan yang digunakan memberikan sebuah tindakan bagi pengambil keputuan dalam mengambil tindakan. Metode dalam pengambilan keputusan disebut Sistem Pendukung Keputusan (Decision Support System). Sistem Pendukung Keputusan merupakan sistem berbasis komputer yang interaktif dengan mengolah data dengan berbagai model-model untuk memecahkan masalah yang tidak terstuktur sehingga dapat memberikan informasi yang dapat digunakan oleh para pengambil keputusan dalam membuat suatu keputusan. Keputusan yang diambil dari hasil pemecahan masalah harus didasari logika dan pertimbangan, penetapan alternatif terbaik harus mendekati tujuan yang telah ditetapkan.

Keputusan dapat memecahkan berbagai masalah seperti bidang pemasaran. Pemasaran dalam bidang bisnis sangat berperan dalam memasarkan produk yang dijual. Sasaran yang tepat menimbulkan kenaikan keuntungan dalam penjualan. Salah satu pemasaran produk yang dipasarkan adalah produk obat sariawan. Banyak produk obat sariawan yang dipasarkan ke masyarakat. Karena banyak produk yang dipasarkan, membuat masyarakat bingung dalam memilih obat sariawan yang paling terbaik. Obat sariawan yang paling banyak diminati masyarakat mengartikan bahwa obat tersebut merupakan obat yang terbaik bagi masyarakat. Pihak perusahaan obat sariawan juga dapat melihat apakah produk mereka diminati masyarakat atau tidak, mengingat tujuan akhir produk dari perusahaan tersebut adalah masyarakat. Produk-produk dari perusahaan laris di distributor atau agen, tidak kemungkinan bagi masyarakat obat sariawan tersebut tidak diminati oleh masyarakat secara langsung. Perlu adanya sistem yang menentukan apakah produk yang paling banyak diminati di masyarakat.

Sistem yang dibangun untuk menentukan produk obat sariwan salah satu nya adalah Sistem Pendukung Keputusan menggunakan Metode AHP (Analytical Hirearchy Process). Metode AHP merupakan suatu bentuk model pendukung keputusan yang menggunakan komponen utamanya adalah sebuah hirarki fungsional dengan input utamanya persepsi manusia. Dengan hirarki, suatu masalah yang kompleks dan tidak terstruktur dipecahkan ke dalam kelompok-kelompok. Kelompok-kelompok tersebut diatur menjadi suatu bagian hirarki. Dalam menganalisa obat panas dalam paling banyak diminati masyarakat, penelitian ini dilandasi oleh penelitian sebelumnya oleh [1] pada studi kasus : Penerapan Metode AHP (Analytical Hirearchy Process) Dalam Sistem Pendukung Keputusan Pemberian Bantuan Dana Kegiatan Ekstrakulikuler Di SMPN 5 Pelahari dengan kesimpulan bahwa sistem pendukung keputusan memudahkan pihak skeolah dalam menentukan dana yang pas untuk kegiatan ektrakulikuler, dan penelitian 
sebelumnya oleh [2] pada studi kasus: Penerapan Metode AHP (Analytical Hirearchy Process) Untuk Menentukan Kualitas Gula Tumbu dengan kesimpulan bahwa metode AHP lebih cepat dibandingkan perhitungan secara manual sehingga lebih efisien dan tingkat keakuratan data sudah mendekati sempurna. Berdasarkan uraian diatas penelitian ini diharapkan dapat menjadi bahan referensi dan rekomendasi bagi masyarakat Siantar simalungun dalam menentukan obat sariawan yang paling terbaik

\section{TEORITIS}

\subsection{Sistem Pendukung Keputusan}

Sistem Pendukung Keputusan merupakan sistem berbasis komputer yang interaktif dengan mengolah data dengan berbagai model-model untuk memecahkan masalah yang tidak terstuktur sehingga dapat memberikan informasi yang dapat digunakan oleh para pengambil keputusan dalam membuat suatu keputusan. Keputusan yang diambil dari hasil pemecahan masalah harus didasari logika dan pertimbangan, penetapan alternatif terbaik harus mendekati tujuan yang telah ditetapkan[3].

Menurut [4] SPK dapat digambarkan sebagai sistem yang berkemampuan mendukung analisis ad hoc data, dan pemodelan keputusan, berorientasi keputusan, orientasi perencanaan masa depan, dan digunakan pada saat-saat yang tidak biasa.

\subsection{Pengertian Analytical Hirearchy Process (AHP)}

Analytic Hierarchy Process (AHP) merupakan suatu teori umum tentang pengukuran yang digunakan untuk menemukan skala rasio, baik dari perbangingan berpasangan yang diskrit maupun kontinyu. AHP menguraikan masalah multi faktor atau multi kriteria yang kompleks menjadi suatu hirarki[5]. Hirarki didefenisikan sebagai suatu representasi dari sebuah permasalahan yang komplek dalam suatu struktur multi level dimana level pertama adalah tujuan, yang diikuti level faktor, kriteria, sub kriteria, dan seterusnya ke bawah hingga level terakhir dari alternatif. Dengan hirarki suatu masalah yang kompleks dapat diuraikan ke dalam kelompok-kelompoknya yang kemudian diatur menjadi suatu bentuk hirarki sehingga permasalahan akan tampak lebih terstruktur dan sistematis[6].

Ada empat buah prinsip dasar AHP yang harus dipahami menurut Hendrawan SA [7]yaitu :

1. Decomposition, yaitu memecah persoalan kompleks ke dalam bentuk yang lebih sederhana dan menyusunnya ke dalam suatu pohon hirarki.

2. Comparative judgment, yaitu proses penilaian mengenai kepentingan relatif antara satu kriteria dengan kriteria lainnya pada suatu tingkat tertentu. Penilaian ini berpengaruh terhadap prioritas kriteria yang merupakan inti dari metode AHP. Hasil penilaian ini disusun dalam bentuk matriks pairwise comparison.

3. Synthesis of priority, yaitu proses sintesis diantara prioritas lokal dalam suatu tingkat hirarki untuk memperoleh prioritas global dari beragam kriteria suatu pengambilan keputusan.

4. Local Consistency, yaitu penilaian kepentingan relatif yang konsisten antara 1 kriteria dengan kriteria lainnya.

Ada beberapa langkah kerja dalam penerapan metode AHP ini, yaitu antara lain[8]:

1. Mendefenisikan struktur hirarki masalah

Permasalahan didekomposisi ke dalam bentuk pohon hirarki yang menunjukkan hubungan antara permasalahan, kriteria, dan alternatif solusi. Pohon hirarki tersebut diilustrasikan dalam gambar berikut :

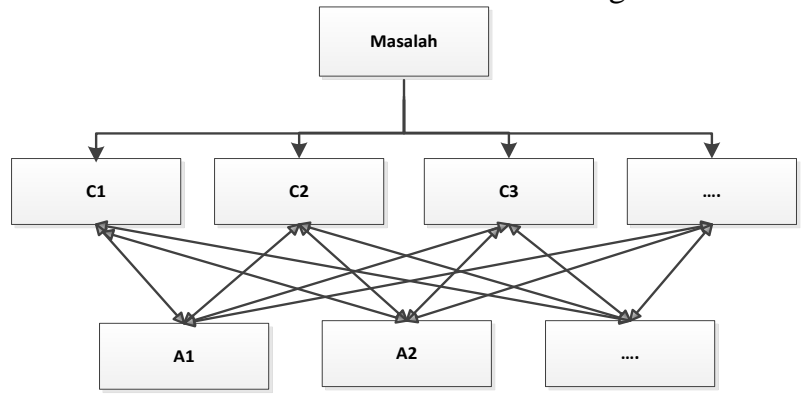

Gambar 1. Pohon Hirarki AHP

2. Melakukan pembobotan kriteria pada setiap tingkat hirarki

Penilaian Kriteria yang berada pada setiap tingkat hirarki diberikan penilaian kepentingan relatif antara satu kriteria dengan kriteria lainnya.

Tabel 1. Skala Perbandingan Berpasangan

\begin{tabular}{ll}
\hline Skala $\mathbf{a}_{\mathbf{i}, \mathbf{j}}$ & \multicolumn{1}{c}{ Keterangan } \\
\hline 1 & Kedua Kriteria sama penting \\
3 & Kriteria i sedikit lebih penting daripada kriteria $\mathrm{j}$. \\
5 & Kriteria i cukup penting daripada kriteria $\mathrm{j}$. \\
7 & Kriteria i lebih penting daripada kriteria j \\
9 & Kriteria i mutlak lebih penting daripada kriteria j.
\end{tabular}


2, 4, 6, 8 Kriteria i dan j memiliki nilai tengan diantara dua nilai keputusan yang berdekatan.

Kebalikan Kriteria i mempunyai nilai kepentingan yang lebih dari kriteria j, maka kriteria j memliki nilai kebalikannya dibanding dengan kriteria i.

Berdasarkan nilai-nilai kriteria tersebut dapat disusun sebuah matriks pairwise comparison A sebagai berikut:

$\begin{array}{llllll}A & a_{1} & a_{2} & a_{3} & \ldots & a_{n} \\ a_{1} & a_{11} & a_{12} & a_{13} & \ldots & a_{1 n} \\ a_{2} & a_{21} & a_{22} & a_{23} & \ldots & a_{2 n} \\ a_{3} & a_{31} & a_{32} & a_{33} & \ldots & a_{3 n} \\ \ldots & \ldots & \ldots & \ldots & \ldots & \ldots \\ a_{m} & a_{1} & a_{2} & a_{3} & \ldots & a_{n}\end{array}$

$\mathrm{a}_{\mathrm{i}, \mathrm{j}}$ Menyatakan elemen matriks A bari Ke- $i$ kolom

3. Menghitung pembobotan kriteria dan konsistensi pembobotan

Tahapan ini menghitung prioritas pembobotan dengan mencari nilai eigenvector dari matriks A melalui proses sebagai berikut :

a. Kuadratkan matriks $A$. Nilai elemen matriks $A^{2}$ ditentukan dengan menggunakan rumus berikut :

$$
a_{i, j}^{2}=\sum_{k=1}^{n} a_{i, k} \cdot a_{k, j}
$$

b. Jumlahkan elemen setiap baris matriks $A^{2}$ sehingga diperoleh suatu matriks $B$ dengan menggunakan rumus berikut :

$b_{i}=\sum_{j=1}^{n} a_{i, j}=a_{i, 1}+a_{i, 2}+a_{i, 3}+\cdots+a_{i, j}$

$b_{i}$ menyatakan elemen matriks $B$ baris ke $i$. Matriks $B$ sisusun menggunakan elemen $b_{i}$ seperti berikut ini :

$$
B=\left[\begin{array}{c}
b_{1} \\
b_{2} \\
b_{3} \\
\cdots \\
\cdots \\
\cdots \\
b_{i}
\end{array}\right]
$$

Jumlahkan seluruh elemen matriks $B$ menggunakan rumus berikut :

$\sum_{i=1}^{n} b_{i,}=b_{1}+b_{2}+b_{3}+\cdots+b_{i}$

c. Dari matriks $B$ yang telah diperoleh pada langkah 2 di atas, selanjutnya dilakukan normalisasi terhadap matriks $B$ untuk memperoleh nilai eigenvector dari matrik $B$ tersebut. Nilai eigenvector dari matriks $B$ ini digambarkan dalam bentuk matriks $E$ sebagai berikut :

$$
E=\left[\begin{array}{c}
e_{1}=b_{1} / \sum_{i=1}^{n} b_{i} \\
e_{2}=b_{2} / \sum_{i=1}^{n} b_{i} \\
e_{i}=b_{i} / \sum_{i=1}^{n} b_{i}
\end{array}\right]
$$

d. Ketika proses di atas dilakukan berulang-ulang dan pada setiap akhir iterasi dicari selisih nilai eigenvector matriks $E$ yang diperoleh dengan nilai eigenvector matriks $E$ sebelumnya sampai diperoleh angka yang mendekati nol. Matriks $E$ yang diperoleh pada langkah terakhir menunjukkan prioritas kriteria yang ditunjukkan oleh koefisien nilai eigenvector.

Penilaian antara satu kriteria dengan kriteria lain tidak bisa sepenuhnya konsisten. Inkonsistensi ini dapat disebabkan oleh kesalahan memasukkan penilaian ke dalam sistem, kurangnya informasi, kurangnya konsentrasi, dunia nyata yang tidak selalu konsisten, atau model struktur hirarki yang kurang sesuai. Metode $A H P$ mengijinkan terjadinya inkonsistensi penilaian kriteria, tetapi inkonsistensi penilaian tersebut tidak boleh melebihi nilai rasio konsistensi sebesar 10\%. Rasio konsistensi ini dapat diperoleh dengan langkah sebagai berikut $[3,5,6]$ :

a. Menghitung $\square$ max dari setiap matriks berorde $\mathrm{n}$ dengan cara menjumlahkan hasil perkalian antara jumlah bobot seluruh kriteria pada masing-masing kolom matriks dengan nilai eigenvector utama dari matriks.

b. Menghitung nilai indeks konsistensi untuk setiap matriks ber-orde $\mathrm{n}$ dengan menggunakan rumus:

$$
\mathrm{CI}=\frac{\lambda \max -\mathrm{n}}{n-1}
$$

Keterangan:

$\mathrm{CR}=$ Consistensi ratio (rasio konsistensi)

$\mathrm{RI}=$ Random index (Indeks acak) untuk setiap matriks berorde $\mathrm{n}$.

Tabel 2 berikut ini menunjukkan nilai indeks acak untuk setiap matriks berorde 1 hingga 10:

Tabel 2. Nilai random index(RI)

\begin{tabular}{ll}
\hline $\mathbf{N}$ & $\mathbf{R I}$ \\
\hline 1 & 0,00 \\
2 & 0,00 \\
3 & 0,58
\end{tabular}


4. Menghitung pembobotan alternatif

\begin{tabular}{ll}
4 & 0,90 \\
5 & 1,12 \\
6 & 1,24 \\
7 & 1,32 \\
8 & 1,41 \\
9 & 1,45 \\
10 & 1,49 \\
\hline
\end{tabular}

Pada tahap ini dilakukan pembobotan alternatif untuk setiap kriteria dalam matriks pairwise comparison. Proses untuk melakukan pembobotan alternatif ini sama dengan proses yang dilakukan untuk menghitung pembobotan kriteria.

5. Menampilkan urutan alternatif yang dipertimbangkan dan memilih alternatif

Tahapan ini menghitung nilai eigenvector yang diperoleh pada pembobotan alternatif untuk setiap kriteria dengan nilai eigenvector yang diperoleh pada pembobotan kriteria. Hal ini dilakukan untuk menentukan pilihan dari alternatif yang tersedia. Jumlah nilai terbesar merupakan pilihan yang terbaik. Perhitungan tersebut ditunjukkan sebagai berikut:

$R=$ Alt $x E$ sehingga diperoleh $R_{a}$ dengan rumus

$R_{a}=\sum_{b=1}^{n} A l t_{a b} \cdot E_{b}$

\subsection{Pengertian Sariawan}

Menurut dr. T Bahdar Johan, Sp.PD dalam [9], sariawan adalah keadaan tubuh manusia yang mengalami panas berlebihan terutama pada bagian mulut, tenggorokan dan sistem pencernaan. Sariawan bisa disebabkan oleh tidak keseimbangan makanan yang bersifat panas dan dingin.

Sariawan disebabkan karena kekurangan Vitamin C, kekurangan serat, kekurangan cairan tubuh (dehidrasi), memakan makanan yang bersifat panas dan berlemak seperti gorengan, atau karena cuaca yang panas.

\section{ANALISA DAN PEMBAHASAN}

\subsection{Analisis Data}

Dalam penelitian ini, data yang digunakan akan diolah dari hasil kuesioner menjadi data mentah yang digunakan untuk proses selanjutnya. Kriteria yang digunakan dalam penelitian ini terdapat 4, yaitu :

1. Harga.

2. Rasa.

3. Komposisi.

4. Penyembuhan.

Kriteria yang digunakan dalam kuesioner terdari dari 4 pilihan yang diajukan kepada masyarakat. Kuesioner yang sudah menjadi data mentah kemudian mencari nilai rata-rata dari setiap produk yang dipilih oleh masyarakat. Pilihan pernyataan menggunakan masing-masing 4 pilihan. Kemudian data diolah menggunakan perhitungan di Microsoft Excel dan di Website. Berikut data yang didapat dalam bentuk mentah pada Tabel 3 :

Tabel 3. Data yang akan diolah

\begin{tabular}{cccccc}
\hline \multirow{2}{*}{ No } & \multirow{2}{*}{ Merk } & \multicolumn{4}{c}{ Produk } \\
\cline { 3 - 6 } & & Harga & Rasa & Komposisi & Penyembuhan \\
\hline 1 & Alang Sari & 3 & 3 & 3 & 3 \\
2 & Alang Sari & 2 & 2 & 2 & 3 \\
3 & Alang Sari & 3 & 3 & 1 & 2 \\
4 & Alang Sari & 2 & 3 & 2 & 2 \\
5 & Alang Sari & 3 & 3 & 3 & 3 \\
6 & Alang Sari & 2 & 2 & 2 & 2 \\
7 & Alang Sari & 3 & 2 & 2 & 2 \\
8 & Alang Sari & 3 & 3 & 1 & 3 \\
9 & Lasegar & 2 & 3 & 1 & 3 \\
$\ldots$ & $\ldots$ & $\ldots$ & $\ldots$ & $\ldots$ & $\ldots$ \\
$\ldots$ & $\ldots$ & $\ldots$ & $\ldots$ & $\ldots$ & $\ldots$ \\
98 & Madu TJ & 2 & 3 & 1 & 2 \\
99 & Madu TJ & 2 & 2 & 2 & 3 \\
100 & Madu TJ & 2 & 3 & 2 & \\
\hline
\end{tabular}

Dari data yang akan diolah dikelompokan dengan kecamatan yaitu:

1. Kecamatan Siantar Barat 35 Responden 
2. Kecamatan Siantar Utara 20 Responden

3. Kecamatan Siantar Sitalasari 19 Responden

4. Kecamatan Siantar Timur 4 Responden

5. Kecamatan Siantar Martoba 2 Responden

6. Kecamatan Siantar Marimbun 10 Responden

7. Kecamatan Pantoan Maju Kabupaten Simalungun 5 Responden

8. Kecamatan Sidamanik Kabupaten Simalungun 4 Responden

9. Kecamatan Panei Kabupaten Simalungun 1 Responden

\subsection{Algoritma AHP}

Permasalahan yang sudah dianalisa, kemudian penulis menentukan produk terbaik dan terfavorit dengan menggunakan Algoritma AHP dengan bahasa pemrograman Website. Algoritma AHP dilakukan untuk memberikan hasil berdasarkan ranking tertinggi dan menjadi keputusan bahwa produk tersebut yang memiliki nilai tertinggi adalah produk yang terbaik dan diberikan penjelasan produk tersebut adalah produk yang terbanyak bagi masyarakat atau tidak. Berikut langkah-langkah dalam perhitungan menggunakan Algoritma AHP :

1. Langkah 1: Mengidentifikasi Struktur Hirarki Masalah

Algoritma ini menggunakan metode Analytict Hirearchy Proces (AHP) dan dimaksudkan untuk membantu dalam menentukan bobot ternormalisasi untuk menghindari kesalahan dalam penentuan bobot ternormalisasi yang cenderung analisa pemikiran seorang pengambilan keputusan. Dalam penentuannya terdapat kriteria-kriteria dan alternatif seperti pada Tabel 3 .

2. Langkah 2: Pembobotan pada setiap Hirarki

Penilaian kriteria yang berada pada setiap tingkat hirarki diberikan penilaian kepentingan relatife antara satu kriteria dengan kriteria lainnya.Tingkat hirarki terdapat pada Tabel 1.

Untuk setiap kriteria dilakukan perbandingan berpasangan (Pairwise Comparison) yaitu membandingkan setiap elemen dengan elemen lainnya.Setiap tingkat hirarki secara berpasangan sehingga didapat nilai tingkat kepentingan elemen dalam bentuk kualitatif.

Tabel 4. Matriks Perbandingan Kriteria

\begin{tabular}{lrrrr}
\hline & Harga & Rasa & Komposisi & Penyembuhan \\
\hline Harga & 1,0000 & 3,0000 & 0,3333 & 0,2000 \\
Rasa & 0,3333 & 1,0000 & 0,5000 & 0,2000 \\
Komposisi & 3,0000 & 2,0000 & 1,0000 & 0,3333 \\
Penyembuhan & 5,0000 & 5,0000 & 3,0000 & 1,0000 \\
\hline
\end{tabular}

3. Langkah 3: Menormalisasikan Matrik Berpasangan

Normalisasi data pada matrik berpasangan antar kriteria dengan cara membagikan kolom ke-i dan baris ke-j dengan jumlah pada kolom i. adapun rumus normalisasi yaitu :

$$
a_{i j}=\frac{a_{i j}}{\sum a_{i j}}
$$

Tabel 5. Matriks Perbandingan Kriteria yang Dijumlahkan

\begin{tabular}{lrrrr}
\hline & Harga & \multicolumn{1}{c}{ Rasa } & Komposisi & Penyembuhan \\
\hline Harga & 1,0000 & 3,0000 & 0,3333 & 0,2000 \\
Rasa & 0,3333 & 1,0000 & 0,5000 & 0,2000 \\
Komposisi & 3,0000 & 2,0000 & 1,0000 & 0,3333 \\
Penyembuhan & 5,0000 & 5,0000 & 3,0000 & 1,0000 \\
Jumlah & 9,3333 & 11,0000 & 4,8333 & 1,7333 \\
\hline
\end{tabular}

Menormalisasikan matrik keputusan dari $a_{i j}$ kemudian dibagikan dengan jumlah pada kolom I, sebagai contoh normalisasi pada kriteria harga :

$\mathrm{a}_{11}=1,0000 / 9,3333=0,1071$

$\mathrm{a}_{21}=0,3333 / 9,3333=0,0357$

$\mathrm{a}_{31}=0,3333 / 9,3333=0,3214$

$\mathrm{a}_{41}=5,0000 / 9,3333=0,5357$

Setelah proses perhitungan normalisasi selesai sampai $\mathrm{a}_{44}$ :

Tabel 6. Matriks Perbandingan Kriteria yang Dinormalisasi

\begin{tabular}{lrlrr}
\hline & Harga & Rasa & Komposisi & Penyembuhan \\
\hline Harga & 0,1071 & 0,2727 & 0,0690 & 0,1154 \\
Rasa & 0,0357 & 0,0909 & 0,1034 & 0,1154 \\
Komposisi & 0,3214 & 0,1818 & 0,2069 & 0,1923 \\
Penyembuhan & 0,5357 & 0,4545 & 0,6207 & 0,5769 \\
Jumlah & 1 & 1 & 1 & 1 \\
\hline
\end{tabular}


4. Langkah 4: Menghitung Rata-Rata Baris (Row Average) pada Matrik Berpasangan

Di peroleh dengan membagikan jumlah perbaris dengan jumlah data yang dibandingkan dengan rumus :

$$
\bar{x}=\frac{\sum i}{n}
$$

Baris $\mathrm{a}_{11}:(0,1071+0,2727+0,0690+0,1154) / 4=0,1411$

Baris $\mathrm{a}_{21}:(0,0357+0,0909+0,1034+0,1154) / 4=0,0864$

Baris $\mathrm{a}_{31}:(0,3214+0,1818+0,2069+0,1923) / 4=0,2256$

Baris $\mathrm{a}_{41}:(0,5357+0,4545+0,6207+0,5769) / 4=0,5470$

5. Langkah 5: Menghitung Weight Sum Vector

Diperoleh dengan mengalikan matrik awal perbandingan kriteria dengan Row Average :

$\begin{array}{lllllll}1,0000 & 3,0000 & 0,3333 & 0,2000 & & 0,1411 & 0,5847 \\ 0,3333 & 1,0000 & 0,5000 & 0,2000 \\ 3,0000 & 2,0000 & 1,0000 & 0,3333 \\ 5,0000 & 5,0000 & 3,0000 & 1,0000 & & 0,0864 \\ 0,2256 & 0,5470\end{array}=\begin{aligned} & 0,3556 \\ & 1,0038 \\ & 2,3609\end{aligned}$

6. Langkah 6: Menghitung Consistency Vector

Diperoleh dengan membagikan Weight Sum Vector dengan Row Average :

$\begin{array}{lll}0,5847 & 0,1411 & 4,1455 \\ 0,3556 & 0,0864 \\ 1,0038 & : & 0,2256 \\ 2,3609 & 0,5470 & 4,4493 \\ 4,3163\end{array}$

7. Langkah 7: Menghitung nilai Lamda Max

Diperoleh dengan rumus :

$\lambda \max =\frac{\sum a}{n}$

Maka $\lambda \max =(4,1455+4,1172+4,4493+4,3163) / 4=4,2571$

8. Langkah 8: Menghitung nilai Konsistensi Index

Menghitung nilai konsistensi index untuk setiap matriks ber-orde $\mathrm{n}$ sebagai berikut :

Maka CI $=(4,2571-4) /(4-1)=0,0857$

9. Langkah 9 : Menghitung nilai Konsistensi Rasio

Terakhir menghitung konsistensi rasio (CR), perhitungan ini digunakan untuk memastikan bahwa nilai konsistensi rasio $(\mathrm{CR})<0,1$. Jika nilai konsistensi rasio $(\mathrm{CR})>0,1$ maka prose perhitungan data harus diulangi dan diperbaiki. Untuk mencari nilai index random tersebut, penulis menghitung RI sesuai dengan jumlah data yang digunakan, terdapat pada Tabel 2. Jika nilai CR lebih besar dari 0,1 maka matrik perbandingan berpasangan harus diperbaiki. Rumus untuk mencari nilai index random :

$$
\mathrm{CR}=\frac{C I}{R I}
$$

Maka, CR $=0,0857 /$ 0,90 = 0,0952 (Konsisten)

10. Langkah 10: Menghitung nilai terhadap Alternatif

Langkah terakhir adalah membandingkan kriteria terhadap seluruh alternatif yang terdiri dari 8 alternatif (produk) Obat Panas Dalam. Untuk perhitungan terhadap alternatif, nilai yang digunakan adalah nilai keseluruhan Row Average Alternatif dikalikan dengan nilai Row Average Kriteria pada Langkah 4. Berikut Nilai Row Average pada setiap Alternatif :

Tabel 7. Row Average

\begin{tabular}{ccccc}
\hline \multirow{2}{*}{ Obat Panas Dalam } & \multicolumn{4}{c}{ KRITERIA } \\
\cline { 2 - 5 } & $\begin{array}{c}\text { Harga } \\
\text { Row Average }\end{array}$ & $\begin{array}{c}\text { Rasa } \\
\text { Row Average }\end{array}$ & $\begin{array}{c}\text { Komposisi } \\
\text { Row Average }\end{array}$ & $\begin{array}{c}\text { Penyembuhan } \\
\text { Row Average }\end{array}$ \\
\hline A1 & 0,2575 & 0,1500 & 0,1250 & 0,1250 \\
A2 & 0,0878 & 0,1500 & 0,1250 & 0,1250 \\
A3 & 0,2575 & 0,1500 & 0,1250 & 0,1250 \\
A4 & 0,0878 & 0,0500 & 0,1250 & 0,1250 \\
A5 & 0,0878 & 0,0500 & 0,1250 & 0,1250 \\
A6 & 0,0461 & 0,1500 & 0,1250 & 0,1250 \\
A7 & 0,0878 & 0,1500 & 0,1250 & 0,1250 \\
A8 & 0,0878 & 0,1500 & 0,1250 & 0,1250 \\
\hline
\end{tabular}

Nilai Row Average pada setiap alternatif terhadap kriteria telah didapatkan, yang terakhir mencari perankingan untuk nilai alternatif tertinggi dengan mengalikan Row Average keseluruhan alternatif terhadap kriteria dengan Row Average kriteria sebagai berikut :

$$
\begin{array}{lllll}
0,2575 & 0,1500 & 0,1250 & 0,1250 \\
0,0878 & 0,1500 & 0,1250 & 0,1250 \\
0,2575 & 0,1500 & 0,1250 & 0,1250
\end{array} \quad \mathrm{X} \quad 0,141053 \quad \begin{array}{ll}
0,1458 & \text { A1 } \\
0,1219 & \text { A2 } \\
0,1458 & \text { A3 }
\end{array}
$$




$\begin{array}{lllllll}0,0878 & 0,0500 & 0,1250 & 0,1250 & 0,086364 & 0,1133 & \text { A4 } \\ 0,0878 & 0,0500 & 0,1250 & 0,1250 & 0,225613 & 0,1133 & \text { A5 } \\ 0,0461 & 0,1500 & 0,1250 & 0,1250 & 0,546969 & 0,1160 & \text { A6 } \\ 0,0878 & 0,1500 & 0,1250 & 0,1250 & & 0,1219 & \text { A7 } \\ 0,0878 & 0,1500 & 0,1250 & 0,1250 & & 0,1219 & \text { A8 }\end{array}$

Berdasarkan perhitungan diatas dapat dilihat bahwa nilai tertinggi terdapat pada Alternatif A1 dan A3, memiliki nilai yang sama sebagai produk terbaik dengan kriteria yang digunakan. Memiliki perbedaan jumlah pembelian Alternatif 1 dengan Alternatif 3 Alternatif 3 memiliki jumlah pembelian lebih banyak daripada Alternatif 1, artinya Alternatif 3 merupakan produk terlaris daripada Alternatif 1.

\section{KESIMPULAN}

Berdasarkan tujuan penelitian, pengolahan data, dan analisa yang telah dilakukan, maka dapat disimpulkan:

1. Dengan menggunakan metode AHP maka di dapatkan alternatif obat sariawan yang paling banyak diminati masyarakat. Data AHP yang di peroleh dari pengisian kuisioner oleh para konsumen kemudian di hitung dan di temukan hasil akhir dan sesuai dengan kriteria yang di inginkan.

2. Berdasarkan perhitungan AHP, di peroleh pemilihan obat sariawan yang paling banyak diminati masyarakat, dimana harga, komposisi, rasa dan penyembuhan menjadi prioritas pihak terkait dalam memilih obata panas dalam yang dimintai masyarakat.

3. Pemilihan obat panas dalam yang paling banyak diminati masyarakat dengan menggunakan metode Analytical Hierarchy Process (AHP) dapat membantu pihak terkait dalam memilih obat sariawan yang sesuai dengan kriteria yang diinginkan. Jadi dengan adanya metode AHP akan mempermudah dan menyederhanakan pengambilan keputusan oleh pihak terkait dengan mempertimbangkan hasil penelitian ini.

\section{REFERENCES}

[1] M. K. Rizqi Elmuna Hidayah, S.Si, Penerapan Metode Ahp ( Analytical Hierarchy Process ) Dalam Sistem Pendukung Keputusan Pemberian Bantuan Dana Kegiatan, Technologia, Vol. 7, No. 3, Pp. 171-176, 2016.

[2] E. Darmanto, N. Latifah, And N. Susanti, Penerapan Metode Ahp ( Analythic Hierarchy Process ) Untuk, J. Simetris, Vol. 5, No. 1, Pp. 75-82, 2014.

[3] D. Walangare, R. Delima, And . R., Sistem Prediksi Pertandingan Sepak Bola Dengan Metode Aho, Informatika, Vol. 8, No. 1, Pp. 181-188, 2015.

[4] S. J. Kuryanti, M. Kom, N. Indriyani, And M. Kom, Penentuan Bonus Pada Karyawan Dengan Menggunakan Metode Analytic Network Process ( Studi Kasus : Pt . Asahimas Flat Glass , Tbk Jakarta ), No. November, Pp. 1-9, 2016.

[5] D. R. Sari, A. P. Windarto, D. Hartama, And S. Solikhun, Sistem Pendukung Keputusan Untuk Rekomendasi Kelulusan Sidang Skripsi Menggunakan Metode Ahp-Topsis, J. Teknol. Dan Sist. Komput., Vol. 6, No. 1, P. 1, 2018.

[6] E. Sestri, Penilaian Kinerja Dosen Dengan Menggunakan Metode Ahp Studi Kasus Di Stie Ahmad Dahlan Jakarta, Vol. 2, No. 1, Pp. 100-109, 2013.

[7] R. Taufiq Et Al., Honorer Menjadi Calon Pegawai Negeri Sipil Dengan Metode Analytical Hierarchy Process (Study Kasus : Badan Kepegawaian Dan Pengembangan Sumber Daya Manusia Kota Tangerang ), No. 2013, Pp. 515-521, 2018.

[8] K. Fatmawati, A. P. Windarto, And M. R. Lubis, Analisa Spk Dengan Metode Ahp Dalam Menentukan Faktor Konsumen Dalam Melakukan Kredit Barang, Vol. I, Pp. 314-321, 2017.

[9] Https://Hellosehat.Com, Mengobati Panas Dalam Dengan Obat Alami Dan Medis. 2019. 